\title{
Platelet-Activating Factor Induces Th17 Cell Differentiation
}

\author{
Anne-Marie Drolet, ${ }^{1,2}$ Maryse Thivierge, ${ }^{1}$ Sylvie Turcotte, ${ }^{1}$ Dominique Hanna, ${ }^{2}$ \\ Bruno Maynard, ${ }^{2}$ Jana Stankovà, ${ }^{1}$ and Marek Rola-Pleszczynski ${ }^{1}$ \\ ${ }^{1}$ Immunology Division, Department of Pediatrics, Faculty of Medicine and Health Sciences, Université de Sherbrooke, Sherbrooke, \\ QC, Canada J1H $5 \mathrm{~N} 4$ \\ ${ }^{2}$ Dermatology Division, Department of Medicine, Faculty of Medicine and Health Sciences, Université de Sherbrooke, Sherbrooke, \\ QC, Canada J1H 5N4
}

Correspondence should be addressed to Marek Rola-Pleszczynski, marek.rola-pleszczynski@usherbrooke.ca

Received 3 June 2011; Accepted 8 August 2011

Academic Editor: Freek Zijlstra

Copyright () 2011 Anne-Marie Drolet et al. This is an open access article distributed under the Creative Commons Attribution License, which permits unrestricted use, distribution, and reproduction in any medium, provided the original work is properly cited.

Th17 cells have been implicated in a number of inflammatory and autoimmune diseases. The phospholipid mediator plateletactivating factor (PAF) is found in increased concentrations in inflammatory lesions and has been shown to induce IL-6 production. We investigated whether PAF could affect the development of Th17 cells. Picomolar concentrations of PAF induced IL-23, IL-6, and IL-1 $\beta$ expression in monocyte-derived Langerhans cells (LCs) and in keratinocytes. Moreover, when LC were pretreated with PAF and then cocultured with anti-CD3- and anti-CD28-activated T cells, the latter developed a Th17 phenotype, with a significant increase in the expression of the transcriptional regulator ROR $\gamma \mathrm{t}$ and enhanced expression of IL-17, IL-21, and IL-22. PAF-induced Th17 development was prevented by the PAF receptor antagonist WEB2086 and by neutralizing antibodies to IL-23 and IL-6R. This may constitute a previously unknown stimulus for the development and persistence of inflammatory processes that could be amenable to pharmacologic intervention.

\section{Introduction}

A unique subset of interleukin (IL)-17-producing $\mathrm{CD}^{+} \mathrm{T}$ helper (Th17) cells, distinct from the well-known Th1 and Th2 cells, was recently identified. The differentiation and persistence of Th17 cells was shown to be dependent on the presence of selected cytokines that include, in humans, IL$1 \beta$, IL-6 [1], and IL-23 [2-4], as well as TGF $\beta$ [5]. Th17 cells secrete a range of cytokines, including IL-17A, IL-17F, IL-21, IL-22, TNF $\alpha$, and IL-6, which have both overlapping and distinct roles in host defense and inflammation [4, 6]. Retinoic orphan receptor-gamma $\mathrm{T}(\mathrm{ROR} \gamma \mathrm{t})^{3}$ and, in humans, its orthologue RORC2 were identified as markers of Th17 cells and shown to be master regulatory transcription factors required for Th17 development [7, 8]. IL-17 appears to play essential roles not only in host defenses against various pathogens, but also in the pathogenesis of chronic inflammatory disorders and in many autoimmune diseases, including multiple sclerosis, inflammatory bowel disease, asthma, and psoriasis [9-15].
Psoriasis is a chronic inflammatory skin disorder characterized by hyperplasia of the epidermis, infiltration of leukocytes into both the dermis and the epidermis, as well as dilatation and growth of blood vessels. Until recently, psoriasis has been considered mainly to be a Th1-driven autoimmune inflammatory disease, but recent findings have clearly revealed a role for IL-23 and Th17 cells. In support of this, an increased number of Th17 cells has been identified in the dermis and epidermis of psoriatic skin compared with normal skin [16], and these cells are activated based on increased IL-17A, IL-17C, IL-17F, and IL-22 expression. Moreover, expression of IL-17A, IL-17F, IL-26, CCL20, and ROR $y$ t, all Th17 markers, were shown to be enhanced in psoriatic skin $[2,17]$. IL-23 was also reported to be highly expressed in lesional psoriatic skin and to be produced by keratinocytes, Langerhans cells (LC), dermal dendritic cells and macrophages $[18,19]$. Finally, resolution of psoriatic lesions has been achieved with the use of several kinds of immune modulators that block the IL-23/Th17 [20]. 
Platelet-activating factor (PAF) is a potent phospholipid inflammatory mediator that is released early in inflammation by a variety of cell types. PAF acts largely by binding to its receptor (PAFR), a G-protein-coupled receptor found on most cells, including platelets, monocytes, mast cells, granulocytes, B lymphocytes, dendritic cells, and keratinocytes [21-24]. PAF is a known regulator of transcription and has been shown to upregulate the secretion of a variety of cytokines, including IL-1, IL-6, and TNF- $\alpha[25,26]$. PAF has been implicated in the pathogenesis of asthma and other allergic conditions, in inflammatory bowel disease, rheumatoid arthritis, multiple sclerosis, endotoxic shock, and dermal inflammation $[23,27,28]$. Several observations suggested a role for PAF in psoriasis. Hence, it was reported that PAF plasma levels were elevated in patients with psoriasis and that lesional psoriatic skin contains substantial amounts of this mediator [29,30]. Histological analysis has shown greater PAFR staining in the epidermis of psoriasis patients compared to controls [31]. A thickened skin with increased proliferation of epidermal keratinocytes, as is seen in psoriasis, was observed in transgenic mice which overexpress PAFR [32].

In the current study, we examined the potential for PAF to induce Th17 development through activation of LC and production of IL-6 and IL-23, in a model of LC-T cell coculture.

\section{Materials and Methods}

2.1. Generation and Isolation of Monocyte-Derived Langerhans Cells. Monocyte-derived LC were generated from human peripheral blood mononuclear leukocytes (PBML) obtained from normal donors following informed consent in accordance with an Internal Review Board-approved protocol, in conformity with the Declaration of Helsinki. Blood monocytes were purified by density gradient centrifugation on Ficoll-Paque (GE healthcare, Piscataway, NJ, USA), followed by plastic adherence, and were cultured for 56 days in 6-well tissue culture plates (Becton Dickinson Labware, Franklin Lakes, NJ, USA) at $2 \times 10^{6} / \mathrm{mL}$ in RPMI 1640 medium supplemented with $10 \%$ (v/v) FBS (PAA Laboratories), rhGM-CSF (20 ng/mL), rhIL-4 (20 ng/mL) and rh-TGF- $\beta$ (10 ng/mL) (Peprotech, Rocky Hill, NJ, USA) at $37^{\circ} \mathrm{C}$ in a humidified $5 \% \mathrm{CO}_{2}$ incubator. On day 3 , fresh medium supplemented with the above mentioned cytokines was added. After 5 days of culture, the outcoming population consisted of typical immature LC to which half-strength concentrations of above mentioned cytokines were added. These LC expressed low levels of CD86, and were negative for CD83 (BD Pharmingen, Mississauga, ON, Canada). They were routinely tested for langerin (Beckman Coulter, Marseille, France) and E-cadherin (R\&D Systems, Minneapolis, Minn, USA) expression, which exceeded $80 \%$ and $75 \%$, respectively.

2.2. Isolation of $\mathrm{CD}^{+} \mathrm{T}$ Cells. $\mathrm{CD} 4^{+} \mathrm{T}$ cells were purified from whole blood lymphocytes by depletion of contaminating cells using a "Human CD $4^{+}$T cell enrichment kit" (Stem
Cell technologies, Vancouver, BC, Canada) following the manufacturer's instructions. Purity was greater than $98 \%$. $\mathrm{CD}^{+} \mathrm{T}$ cells at $0.5 \times 10^{6}$ cells/mL in RPMI $164010 \% \mathrm{FBS}$ were then incubated for 5 days with a combination of antiCD3 $(2 \mu \mathrm{g} / \mathrm{mL})$, immobilized on microplates, and soluble anti-CD28 $(1 \mu \mathrm{g} / \mathrm{mL})$ antibodies. The treatment was effective in inducing $\mathrm{T}$ cell blastogenesis.

2.3. Coculture of PAF-Stimulated MoLC with T Cells. T cells were plated at $1 \times 10^{5}$ cells/well and either stimulated alone with a combination of IL- $1 \beta+$ IL- 6 + IL-23 (Peprotech, Rocky Hill, NJ and Alexis Biochemicals, San Diego, Calif, USA) for 5 days or cocultured with $2.5 \times 10^{4}$ autologous LC in the absence or presence of graded concentrations of PAF $\left(10^{-12}\right.$ to $10^{-7} \mathrm{M}$ ) (octadecyl-PAF, Cayman, Ann Arbor, Mich, USA). When indicated, neutralizing Ab for IL-6R, IL-15 or IL-23p19 (R\&D Systems) were used at $0.4 \mu \mathrm{g} / \mathrm{mL}$, $0.5 \mu \mathrm{g} / \mathrm{mL}$ and $0.8 \mu \mathrm{g} / \mathrm{mL}$, respectively. Cultures were used after 5 days for cytometry and PCR analysis. When indicated, inhibitors of Jak2 (AG490), EGFR (EGFR Inhibitor), NF$\kappa \mathrm{B}(\mathrm{NF}-\kappa \mathrm{B}$ Activation Inhibitor) or STAT3 (STAT3 Inhibitor Peptide), all from EMD Biosciences, San Diego, Calif, USA, were at $10 \mu \mathrm{M}, 20 \mu \mathrm{M}, 20 \mu \mathrm{M}$ and $400 \mu \mathrm{M}$, respectively.

2.4. Keratinocyte Cultures. The A431 human keratinocytic squamous cell carcinoma cell line, was obtained from the American Type Culture Collection and cultured at $37^{\circ} \mathrm{C}$ in high-glucose DMEM (Gibco BRL, Grand Island, NY, USA) supplemented with 10\% fetal bovine serum (FBS) (PAA Laboratories, Etobicoke, ON, Canada).

Normal human neonatal foreskin epidermal keratinocytes (NHEK cells) were obtained from Lonza (Walkersville, Md, USA). NHEK cells were grown in serumfree medium, KGM-2 (Lonza), containing $0.09 \mathrm{mmol} / \mathrm{L}$ $\mathrm{CaCl}_{2}, 0.5 \mathrm{mg} / \mathrm{mL}$ hydrocortisone, $0.1 \mathrm{ng} / \mathrm{mL}$ recombinant human epidermal growth factor (EGF), $5 \mathrm{ng} / \mathrm{mL}$ insulin, $0.4 \% \mathrm{v} / \mathrm{v}$ bovine pituitary extract, $50 \mathrm{mg} / \mathrm{mL}$ gentamycin and $0.05 \mathrm{mg} / \mathrm{mL}$ amphotericin $\mathrm{B}$, in an atmosphere of $95 \%$ air and $5 \% \mathrm{CO}_{2}$ at $37^{\circ} \mathrm{C}$. NHEK cells were used in the proliferative phase at $70 \%-80 \%$ confluency.

2.5. Flow Cytometry Analysis. For the last $3 \mathrm{~h}$ of coculture, cells were stimulated with $25 \mathrm{ng} / \mathrm{mL}$ PMA (Sigma-Aldrich, Oakville, ON, Canada) and $1 \mu \mathrm{g} / \mathrm{mL}$ ionomycin (EMD chemicals, La Jolla, Calif, USA) in the presence of $2 \mathrm{mM}$ monensin (BD Biosciences, Mississauga, ON, Canada) for assessment of intracellular IL-17A. Cells were then washed in Fix/Perm solution (eBioscience, San Diego, Calif, USA) according to the manufacturer's instructions and stained for CD4 (BD biosciences) and intracellular IL-17A or $\mathrm{ROR} \gamma \mathrm{t}$ (eBioscience) for 30 minutes. After washing, cells were analyzed on a FACSCalibur flow cytometer using the CellQuestPro software.

2.6. RNA Isolation and Real-Time Quantitative PCR. RNA was obtained using Trizol reagent (Invitrogen, Burlington, ON, Canada) according to the manufacturer's instructions. After total RNA purification with Rneasy kit (Qiagen, 
Mississauga, ON, Canada), $1.0 \mu \mathrm{g}$ of RNA was converted to cDNA with oligo dT (Fermentas, Burlington, ON, Canada) and reverse transcriptase (M-MLV; Promega, Madison, WI, USA) in a volume of $20 \mu \mathrm{L}$. GAPDH, IL-6, IL-17A, IL-21, IL22, IL-23p19, PAF receptor (PAFR) and RORC2 expression were measured using real-time PCR performed on a RotorGene 3000 (Corbett Research, Kirkland, QC, Canada). The following oligonucleotide primer sets were obtained from IDT (Coralville, Ind, USA): human GAPDH: forward, 5GAT GAC ATC AAG AAG GTG GTG AA-3 and reverse, 5-GTC TTA CTC CTT GGA GGC CAT GT-3; human IL6: forward, 5-GTG TGA AAG CAG CAA AGA GGC-3 and reverse, 5-CTG GAG GTA CTC TAG GTA TAC-3; human IL-17A: forward, 5-CTA CAA CCG ATC CAC CTC AC3 and reverse, 5-CCA CGG ACA CCA GTA TCT TC-3; human IL-21: forward, 5-GCA ACA TGG AGA GGA TTG TC-3 and reverse, 5-CTG AAA GCA GGA AAA AGC TG3; human IL-22: forward, 5-CAC AGA CGT TCG TCT CAT TG-3 and reverse, 5-AGC TTT TGC ACA TTC CTC TG3; human IL-23p19: forward, 5-GAT GTT CCC CAT ATC CAG TG-3 and reverse, 5-ATC TGC TGA GTC TCC CAG TG-3; human PAFR: forward, 5-CCT CCT TAG CAC CAA CTG TGT C-3 and reverse, 5-CAA CCA CTT CAG TGA CCG TAT CC-3; human RORC2: forward, 5-CAG TCA TGA GAA CAC AAA TTG AAG TG-3 and reverse, 5-CAG GTG ATA ACC CCG TAG TGG AT-3. Each sample for the real-time PCR consisted of: $1 \mu \mathrm{L}$ cDNA, $2.5 \mathrm{mM} \mathrm{MgCl}_{2}$, $100 \mu \mathrm{M}$ dNTP, $1 \mu \mathrm{M}$ of primers, $2.5 \mu \mathrm{L}$ of $10 \mathrm{X}$ PCR buffer, 0.5 unit of Taq polymerase (Feldan Bio Laboratories Inc, Québec, QC, Canada) and $0.8 \mu \mathrm{L}$ of SYBR Green (Molecular Probe, Eugene, OR; 1/1000 stock dilution) in a reaction volume of $25 \mu \mathrm{L}$. The cycling program consisted of an initial denaturation at $95^{\circ} \mathrm{C}$ for $5 \mathrm{~min}, 45$ cycles of amplification conditions as follows: $95^{\circ} \mathrm{C}(30 \mathrm{sec}), 58^{\circ} \mathrm{C}(30 \mathrm{sec}), 72^{\circ} \mathrm{C}$ $\left(30 \mathrm{sec}\right.$ ), and a final extension at $72^{\circ} \mathrm{C}$ for $6 \mathrm{~min}$. Each gene expression was normalized with GAPDH mRNA content and fold differences were calculated with the delta-delta $(\Delta \Delta) \mathrm{Ct}$ method according to the following formula: $(\Delta \Delta \mathrm{Ct}$ $=[(\mathrm{Ct}$ G.O.I.Ctl $-\mathrm{Ct}$ HK.G.Ctl $)-(\mathrm{Ct}$ G.O.I.STIM. $-\mathrm{Ct}$ HK.G.STIM.)]. Comparison of the expression of each gene between its control and stimulated states was determined by its $\Delta \Delta$ Ct. Results were then transformed into fold variation measurements: fold increase $=2^{\Delta \Delta \mathrm{Ct}}$

2.7. Statistical Analysis. Statistical significance was calculated using Prism 5 software (GraphPad Software, San Diego Calif, USA). For analysis of differences between experimental groups, Student's $t$-test and one-way and two-way ANOVA with Bonferroni posttest were used, as appropriate. Values of $P \leq 0.05$ were considered statistically significant.

\section{Results}

3.1. PAF Induces IL-23, IL-6, and IL-1 $\beta$ Production. In order to assess the potential for PAF to modulate Th17 cell development, we initially exposed monocyte-derived LC to graded concentrations of PAF and measured their capacity to express IL-23p19, IL-6, and IL-1 $\beta$ mRNA. As shown in
Figure 1, picomolar concentrations of PAF increased both IL23 , IL- 6 and IL- $1 \beta$ gene expression in a 4 -hr culture, with significant effects at PAF concentrations of $10^{-11}$ to $10^{-9} \mathrm{M}$.

Since keratinocytes also express receptors for PAF (PAFR) [22], we tested whether PAF could also induce cytokine expression in these cells. As shown in Figure 2, PAF induced the expression of IL-23p19, IL-6 and IL-1 $\beta$ mRNA in both A431 keratinocytic cells (Figures 2(a), 2(b), and 2(c)) and normal human epidermal keratinocytes (NHEK) (Figures 2(d), 2(e), and 2(f)) with significant increases at PAF $10^{-10}$ to $10^{-8} \mathrm{M}$.

3.2. PAF-Activated LC Induce Th17 Cell Development. Since antigen-presenting cells, such as LC can modulate T helper cell polarization, we investigated whether PAF activation of LC could induce the development of a Th17 phenotype in cocultured autologous $\mathrm{CD}^{+} \mathrm{T}$ cells. During the 5-day differentiation of monocytes into LC, we activated autologous $\mathrm{T}$ cells with anti-CD3 and anti-CD28 Ab. Monocytederived LC expressed both PAFR mRNA and protein, and were capable of responding to PAF with calcium flux and chemotaxis. In contrast, activated $\mathrm{CD} 4^{+} \mathrm{T}$ cells expressed no PAFR mRNA and failed to respond to PAF in either calcium flux or chemotaxis.

Following their 5-day differentiation, LC were treated with graded concentrations of PAF and put in a coculture with activated autologous $\mathrm{T}$ cells for an additional 5-day period at a ratio of $1: 5$. T cells were then analyzed by flow cytometry for expression of the transcriptional regulator ROR $\gamma t$ and for IL-17. As shown in Figures 3(a) and 3(b), PAF-activated LC significantly enhanced both ROR $\gamma \mathrm{t}$ and IL-17 expression in preactivated and cocultured $\mathrm{CD}^{+} \mathrm{T}$ cells. Induction of ROR $\gamma \mathrm{t}$ expression in $\mathrm{T}$ cells by PAFpretreated LC was of a similar magnitude as that induced in activated $\mathrm{T}$ cells cultured in the presence of IL-1 $\beta$, IL6 , and IL-23 without LC. As expected, PAF-induced ROR $\gamma \mathrm{t}$ expression in $\mathrm{T}$ cells was prevented by pretreatment of LC with the PAFR antagonist WEB2086 before exposure to PAF, whereas cytokine-induced ROR $\gamma t$ expression was unaffected (Figure 2(c)). Interestingly, exposure of LC to WEB2086 lowered their basal level of ROR $\gamma t$ induction, suggesting that basal ROR $\gamma \mathrm{t}$ expression was dependent on PAFR activation, potentially by endogenous production of PAF or PAF-like compounds by LC.

3.3. PAF-Induced Th17 Development Is Associated with Enhanced Production of IL-17A, IL-21, IL-22, and RORC2. Th17 development following coculture with PAF-treated LC was accompanied by expression of Th17-associated cytokines by the $\mathrm{CD}^{+} \mathrm{T}$ cell population, namely IL-17A, IL-21, and IL-22, as well as RORC2, the closest human homologue of mouse ROR $\gamma$ t. As shown in Figure 4, subnanomolar concentrations of PAF were able to induce a significant increase in IL-17A, IL-21, IL-22, and RORC2 mRNA expression. Interestingly, the PAF-induced LC-dependent levels were similar to those induced by direct $\mathrm{T}$ cell activation with the combination of IL- $1 \beta$, IL-6, and IL-23, except for IL22 , which was expressed more strongly in directly activated 


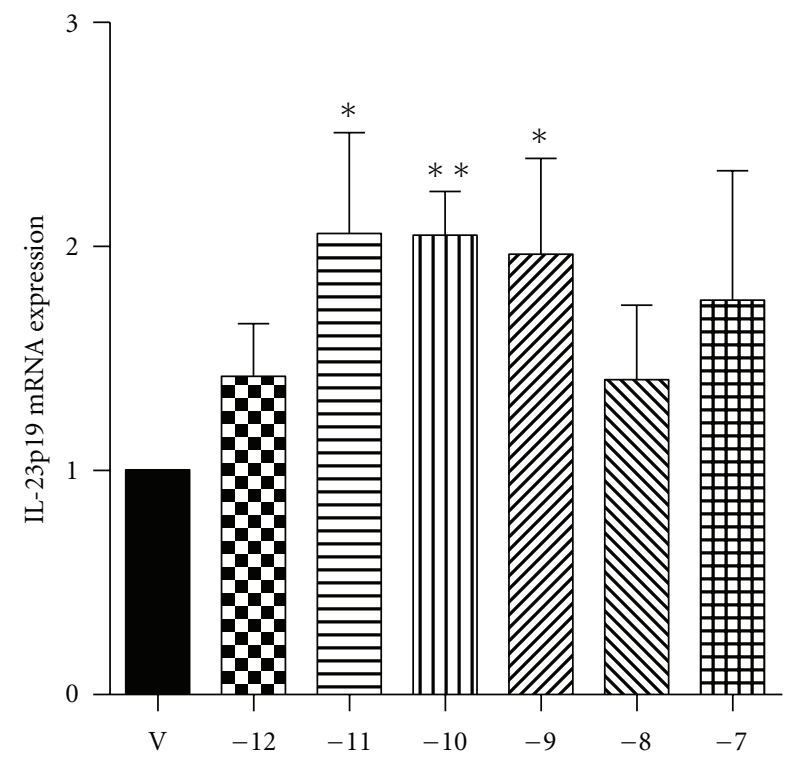

$[\mathrm{PAF}] \log _{10}(\mathrm{M})$

(a)

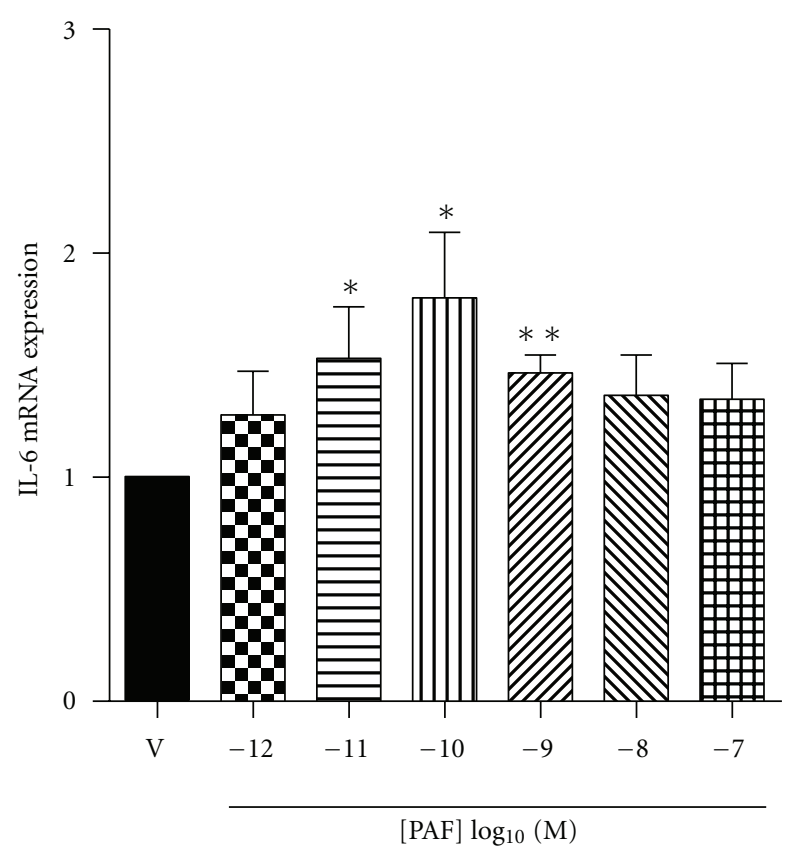

(b)

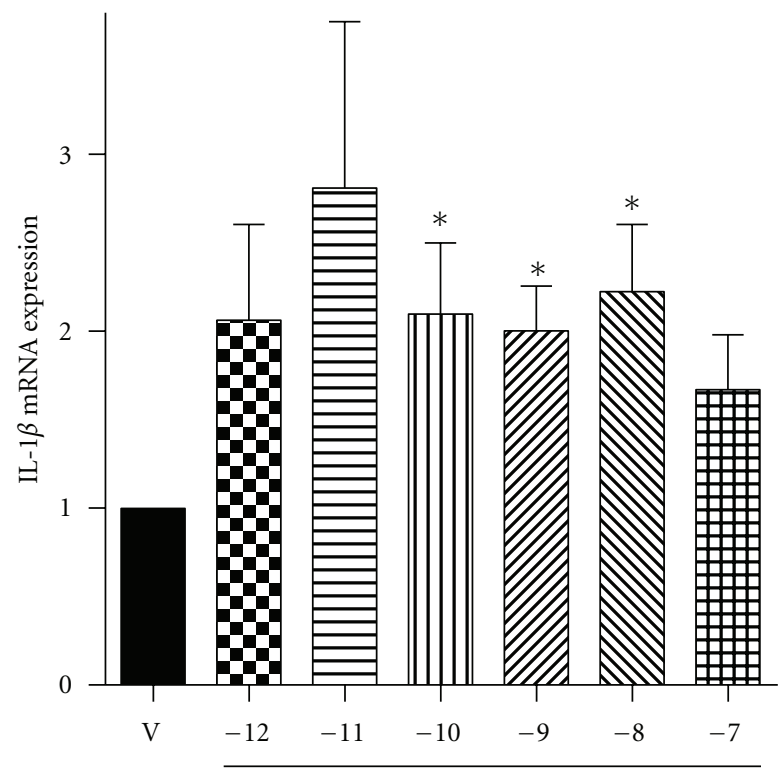

$[\mathrm{PAF}] \log _{10}(\mathrm{M})$

(c)

FIgURE 1: PAF-induced IL-6 and IL-23p19 mRNA expression in LC. Monocyte-derived LC were stimulated with graded concentrations of PAF or its vehicle (ethanol; V) for 4 h. IL-23 p19 (a), IL-6 (b), and IL-1 $\beta$ (c) mRNA was then measured by real-time quantitative PCR. Data (means \pm SEM) are expressed as fold induction relative to vehicle control. $n=9{ }^{*} P<0.05 ; * * P<0.01$.

$\mathrm{T}$ cells. In contrast, purified $\mathrm{CD} 4^{+} \mathrm{T}$ cells, either freshly isolated or activated for 5 days with anti-CD3/anti-CD28 Ab, failed to upregulate their expression of IL-17A or RORC2 in response to PAF (data not shown).

3.4. PAF-Induced Th17 Development Is Dependent on IL-23 and IL-6. We next investigated whether PAF-induced devel- opment of Th17 differentiation was dependent on cytokines produced by LC. Since IL-15, a proinflammatory cytokine, synthesized mainly by LC and DC, has also been suggested as an inducer of Th17 cell development [33, 34], we also used neutralizing anti-IL-15 Ab in our assays. We thus added neutralizing anti-IL-6R, anti-IL-23 and/or anti-IL-15 Ab to the LC-T cell cocultures and measured ROR $\gamma$ t expression 


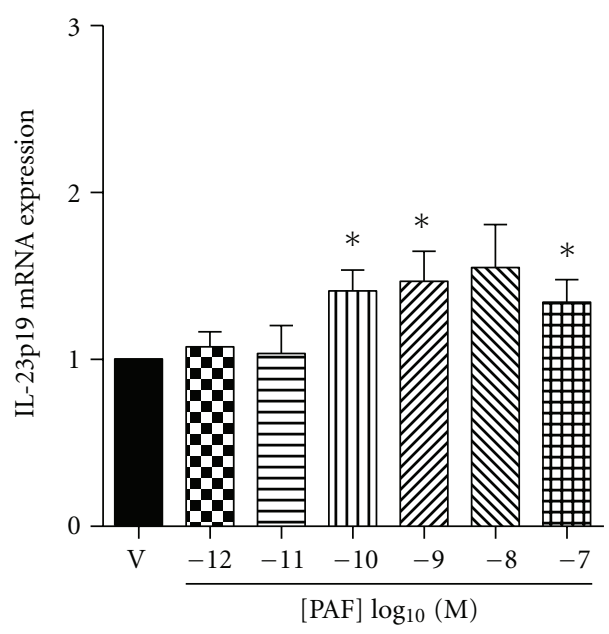

(a)

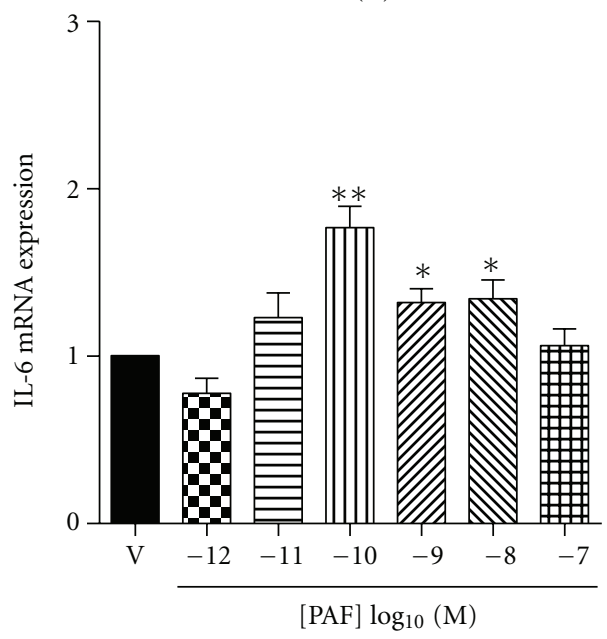

(b)

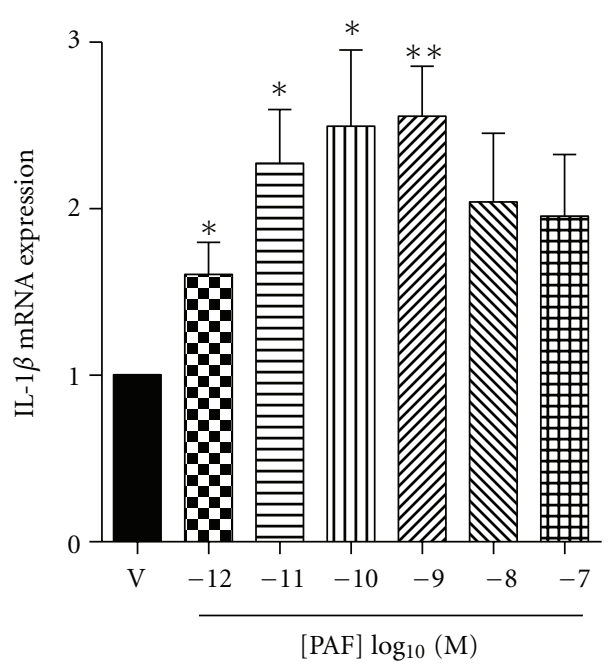

(c)

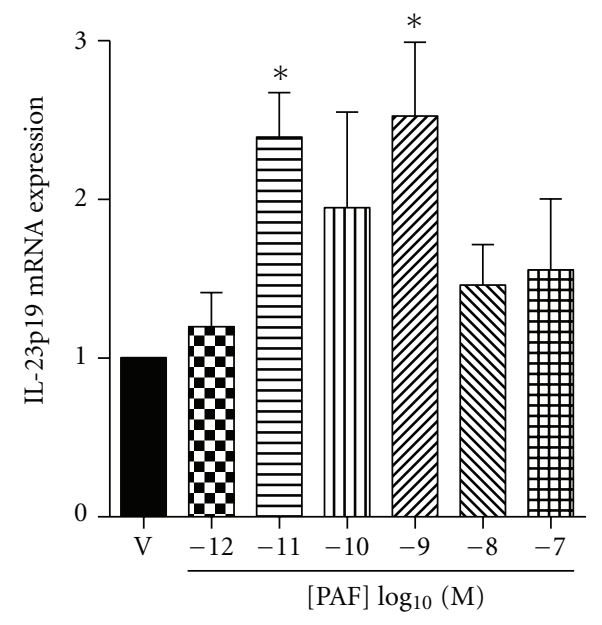

(d)

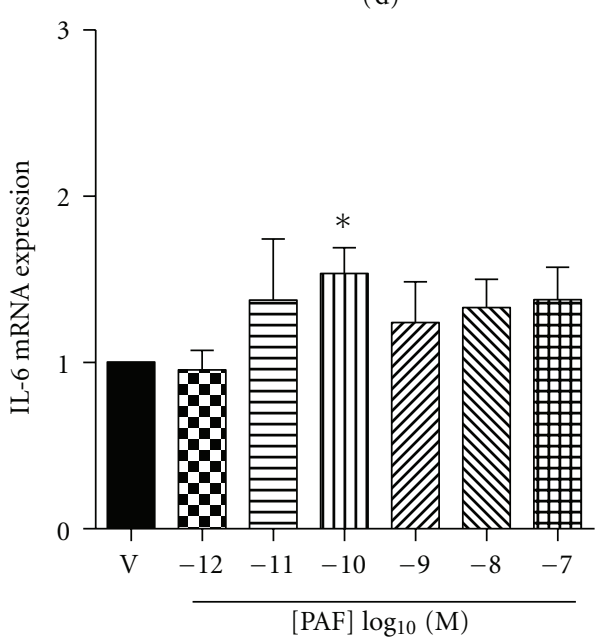

(e)

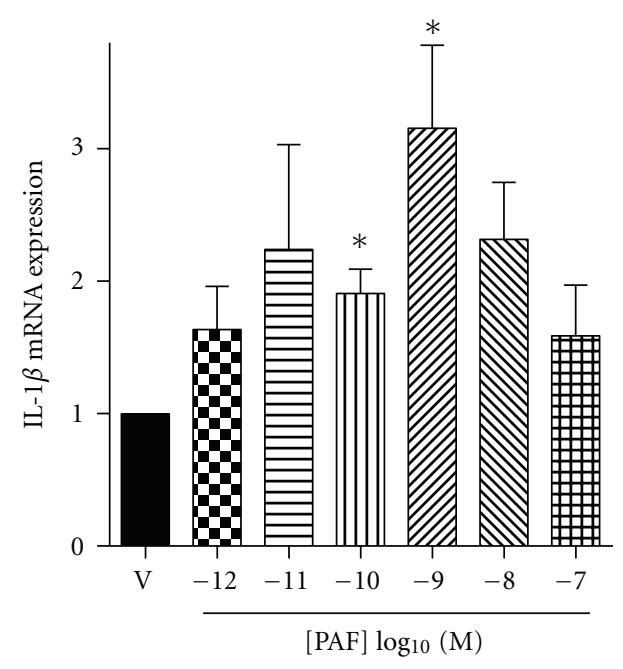

(f)

Figure 2: PAF-induced IL-23p19, IL-6, and IL-1 $\beta$ mRNA expression in A431 keratinocytic cells ( $a, b, c)$ and normal human epidermal keratinocytes (NHEK; d, e, f). Cells were stimulated with graded concentrations of PAF or its vehicle (ethanol; V) for 4 h. IL-23 p19 (a, d), IL-6 (b, e), and IL-1 $\beta$ (c, f) mRNA was then measured by real-time quantitative PCR. Data (means \pm SEM) are expressed as fold induction relative to vehicle control. $n=8 ;{ }^{*} P<0.05 ;{ }^{* *} P<0.01$. 


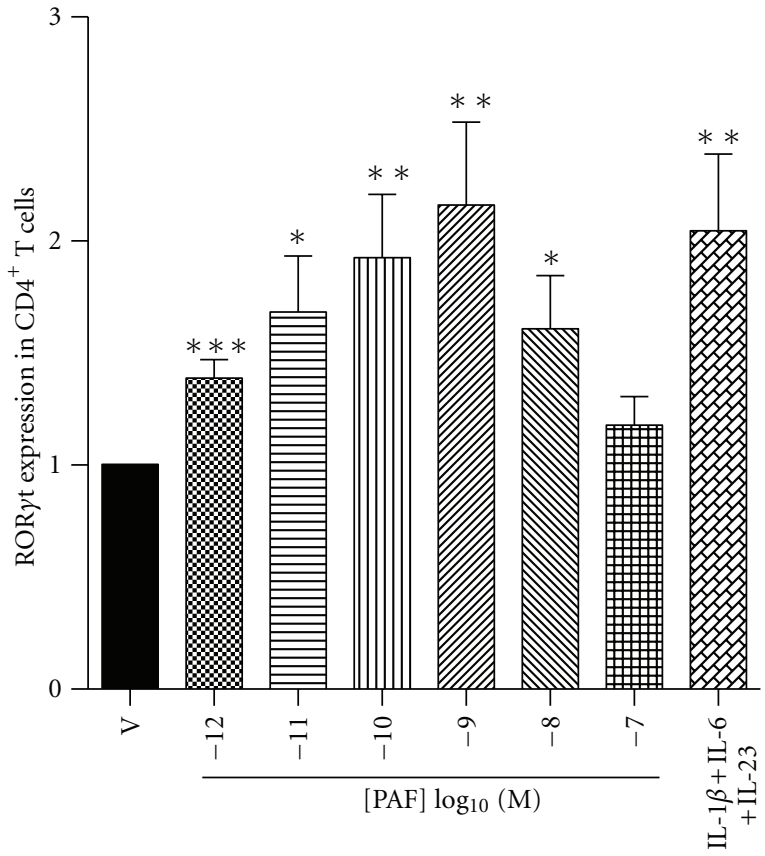

(a)

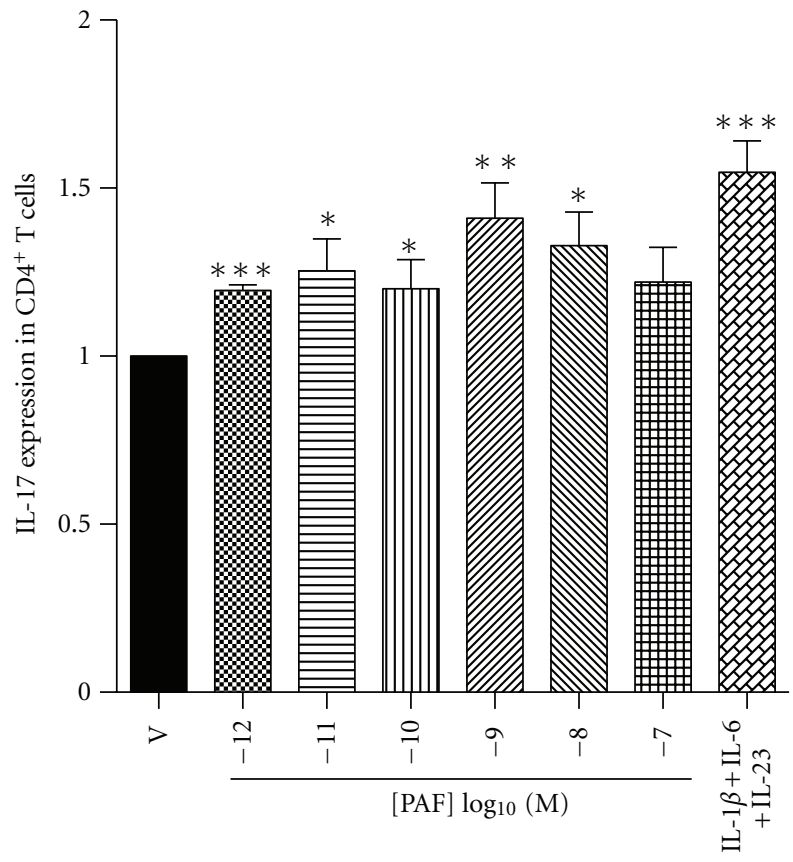

(b)
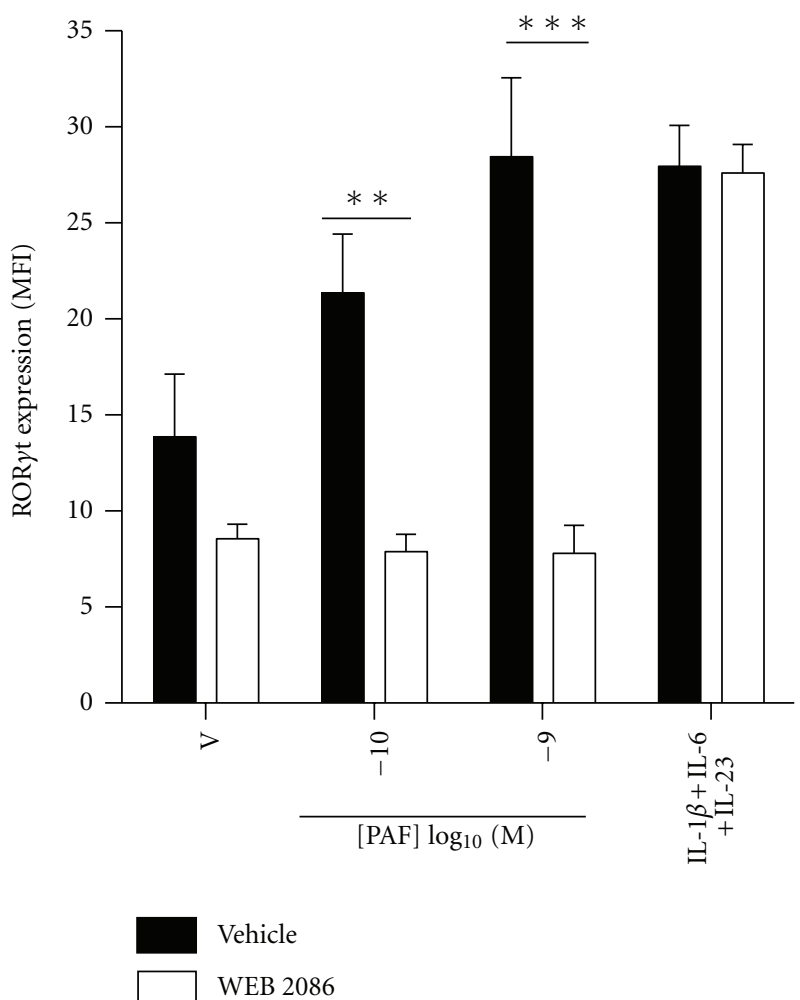

(c)

FIgURe 3: PAF-stimulated LC induce a Th17 phenotype in cocultured T cells. Monocyte-derived LC were stimulated with graded concentrations of PAF or its vehicle (ethanol; V) and cocultured with antiCD3/CD28-activated CD4 ${ }^{+}$T cells for 5 days. ROR $\gamma$ t (a) and IL-17 (b) expression was measured by FACS in CD4 ${ }^{+} \mathrm{T}$ cells. For comparison, CD4 ${ }^{+} \mathrm{T}$ cells were cultured alone with IL- $1 \beta$, IL-6, and IL-23 for 5 days. Data (means \pm SEM) are expressed as fold induction relative to vehicle (V) control. $n=10 ;{ }^{*} P<0.05$; ${ }^{* *} P<0.01$; ${ }^{* * *} P<0.001$. (c) LC were also stimulated with either vehicle or PAF in the absence or presence of the PAFR antagonist WEB $2086\left(10^{-5} \mathrm{M}\right)$ and cocultured with anti-CD3/CD28-activated CD $4^{+}$T cells for 5 days. ROR $\gamma$ t expression was measured by FACS in CD4 ${ }^{+}$T cells and expressed as geometric mean $\left( \pm\right.$ SEM) fluorescence intensity (MFI). $n=5$; ${ }^{* *} P<0.01$; ${ }^{* * *} P<0.001$. 


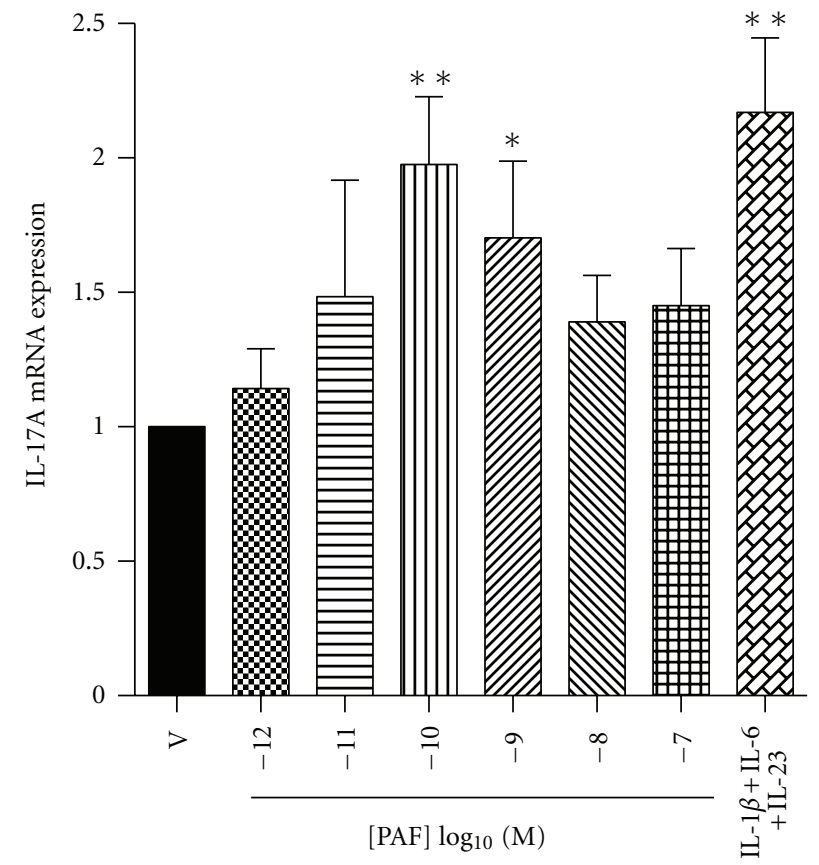

(a)

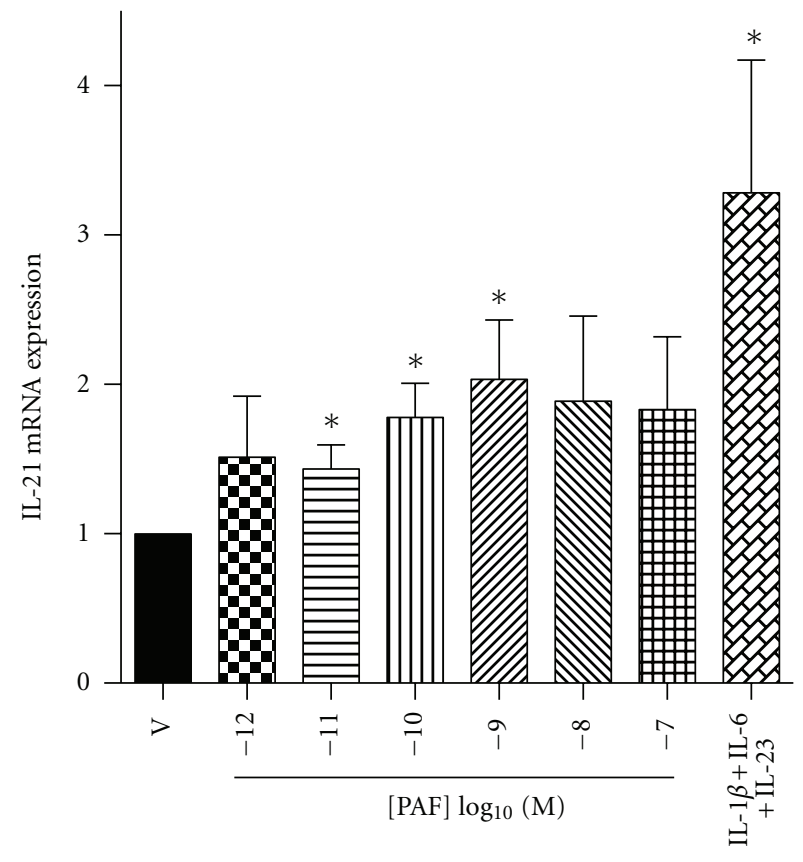

(c)

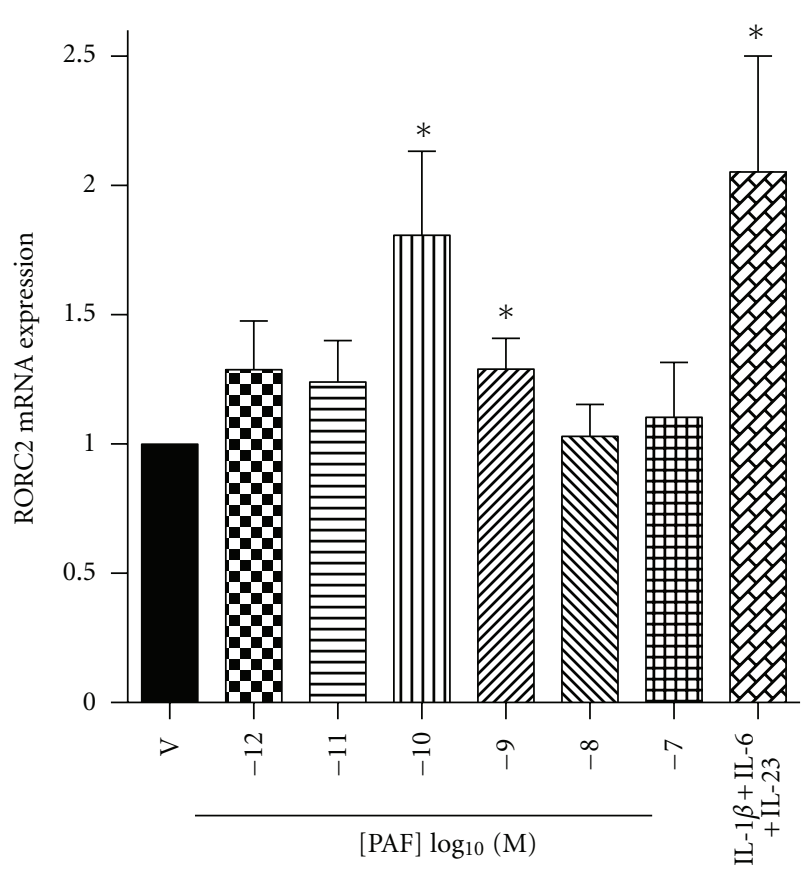

(b)

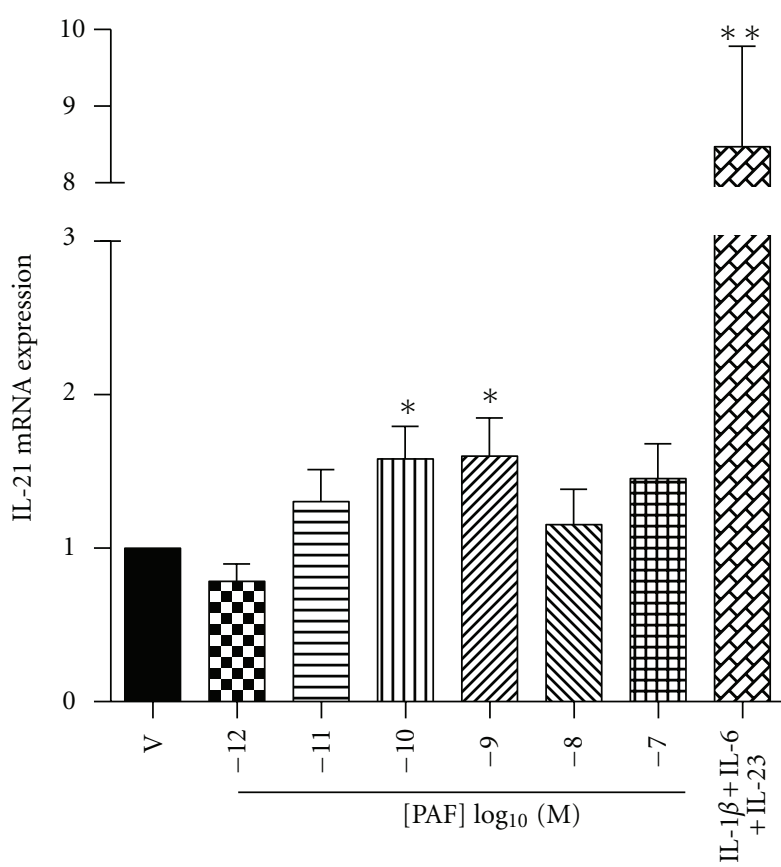

(d)

FIgURE 4: PAF-stimulated LC induce Th17 mRNA markers in cocultured T cells. Monocyte-derived LC were stimulated with graded concentrations of PAF or its vehicle (ethanol; V) and cocultured with antiCD3/CD28-activated CD4 ${ }^{+} \mathrm{T}$ cells for 5 days. IL-17A (a), RORC2 (b), IL-21 (c), and IL-22 (d) mRNA expression was measured by real-time quantitative PCR in CD4 ${ }^{+} \mathrm{T}$ cells. For comparison, CD4 ${ }^{+} \mathrm{T}$ cells were cultured alone with IL-1 $\beta$, IL-6, and IL-23 for 5 days. Data (means \pm SEM) are expressed as fold induction relative to vehicle (V) control. $n=8$; $^{*} P<0.05$; ${ }^{*} P<0.01$.

in $\mathrm{CD}^{+} \mathrm{T}$ cells after 5 days. As shown in Figure 5(a), addition of $\mathrm{Ab}$ directed against IL-23 or IL-6R resulted in a markedly decreased induction of ROR $\gamma \mathrm{t}$ expression. In contrast, neutralization of IL-15 had no effect. Our data suggest that IL-23 and IL-6, but not IL-15, are essential for LC-dependent, PAF-induced Th17 development.
3.5. PAF-Induced Th17 Development Is Dependent on LC$T$ Cell Contact. Since antigen-presenting cells need to physically interact with $\mathrm{T}$ cells at different stages of the immune response, we tested whether cell-cell contact between PAF-primed LC and TCR-activated T cells was essential for Th17 development. As shown in Figure 5(b), 


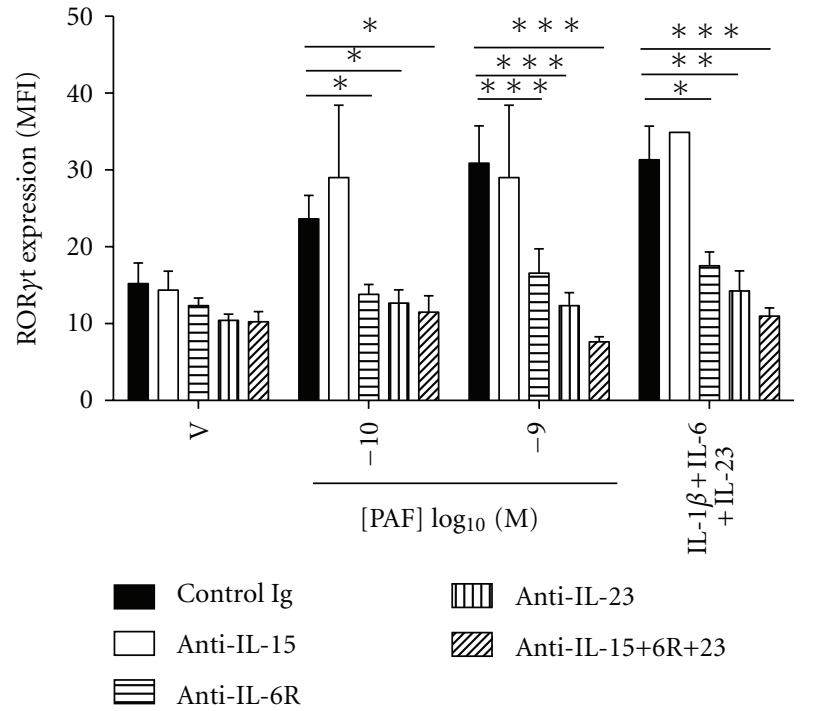

(a)

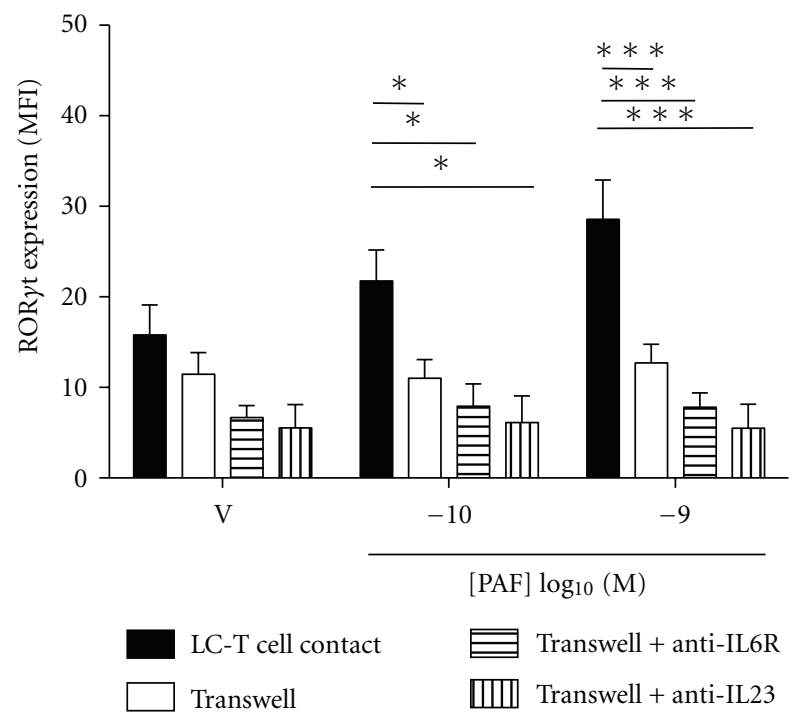

(b)

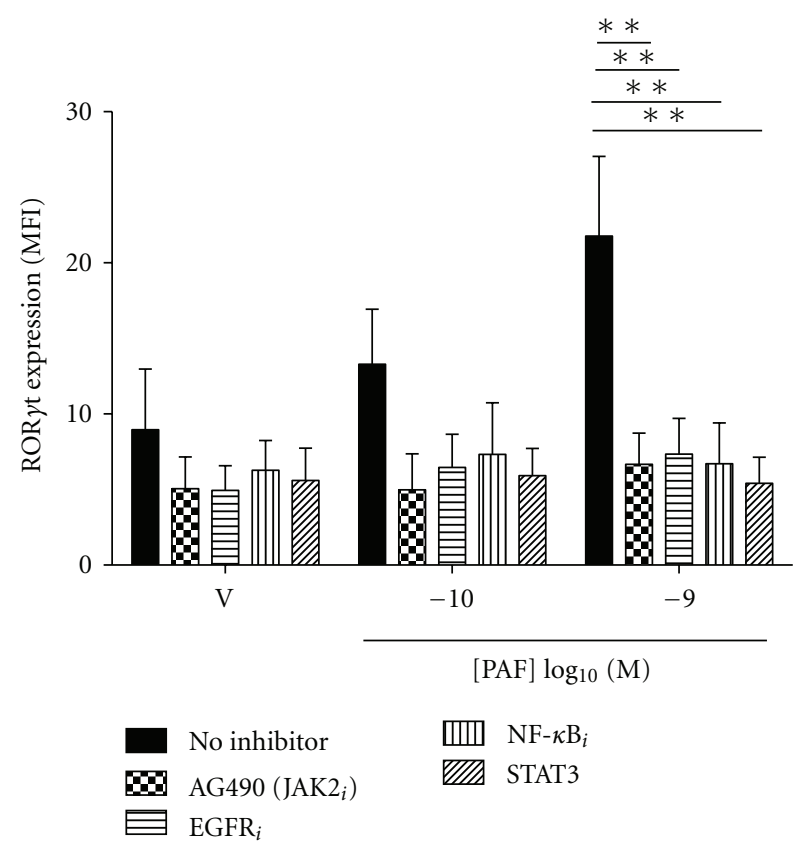

(c)

FIGURE 5: PAF-stimulated Th17 development is dependent on cytokines, LC-T cell contact and selected signaling pathways. (a) Monocytederived LC were stimulated with either vehicle or PAF in the presence of neutralizing Ab to IL-15, IL-6R, and/or IL-23, or control Ig, and cocultured with antiCD3/CD28-activated CD4 ${ }^{+} \mathrm{T}$ cells for 5 days. For comparison, CD4 ${ }^{+} \mathrm{T}$ cells were cultured alone with IL-1 $\beta$, IL- 6 and IL-23 for 5 days in the absence or presence of the above-indicated neutralizing Ab. ROR $\gamma t$ expression was measured by FACS in CD ${ }^{+}$T cells and expressed as geometric mean $\left( \pm\right.$ SEM) fluorescence intensity (MFI). $n=5 ;{ }^{*} P<0.05 ; * * P<0.01$; *** $P<0.001$. (b) LC were stimulated with either vehicle or PAF and cocultured with antiCD3/CD28-activated CD4 ${ }^{+} \mathrm{T}$ cells for 5 days with direct LC-T cell contact or separated by a Transwell filter (LC in the top chamber, T cells in the bottom), in the absence or presence of neutralizing Ab to IL-6R or IL-23. ROR $\gamma \mathrm{t}$ expression was measured by FACS in $\mathrm{CD} 4^{+} \mathrm{T}$ cells and expressed as geometric mean $( \pm \mathrm{SEM})$ fluorescence intensity $(\mathrm{MFI}) . n=5 ;{ }^{*} P<0.05$; ${ }^{* * *} P<0.001$. (c) LC were stimulated with either vehicle or PAF and cocultured with antiCD3/CD28-activated CD $4^{+} \mathrm{T}$ cells for 5 days in the absence or presence of inhibitors of Jak2, EGFR, NF- $\kappa$ B, or STAT3. ROR $\gamma$ t expression was measured by FACS in CD4 ${ }^{+}$T cells and expressed as geometric mean $( \pm \mathrm{SEM})$ fluorescence intensity $(\mathrm{MFI}) . n=4 ;{ }^{*} P<0.01 ;{ }^{* *} P<0.001$.

ROR $\gamma$ t expression in $\mathrm{CD}^{+} \mathrm{T}$ cells was prevented when LC were separated from $\mathrm{T}$ cells by a Transwell membrane, indicating that indeed PAF-induced Th17 development was also dependent on LC-T cell contact.
3.6. PAF-Induced Th17 Development Is Dependent on Jak2, STAT3, NF- $\kappa B$, and EGFR. We have previously shown that PAFR signaling could induce Jak2 phosphorylation and STAT3 translocation in monocytes [35]. Moreover, PAF 
had been shown to induce the production of heparinbinding epidermal growth factor like growth factor (HBEGF) through an NF- $\kappa$ B-dependent mechanism [36] and to transactivate the epidermal growth factor receptor (EGFR) [37]. STAT3 and NF- $\kappa \mathrm{B}$ were also found to be required for IL-23 mediated IL-17 production [38]. When LC were pretreated with cell-permeable inhibitors of Jak2, EGFR, NF$\kappa \mathrm{B}$ or STAT3, ROR $\gamma \mathrm{t}$ expression in $\mathrm{CD} 4^{+} \mathrm{T}$ cells was totally prevented (Figure 5(c)), suggesting that the Jak-STAT, NF- $\kappa \mathrm{B}$ and EGFR signaling pathways were involved in PAF-induced Th17 development.

\section{Discussion}

The expression of IL-23 is highly enhanced in lesional psoriatic skin and this Th17-inducing factor is produced by keratinocytes, Langerhans cells, dermal dendritic cells and macrophages [19]. The immunogenicity of skin correlates with a substantial number of resident DCs including epidermal Langerhans cells (LCs) and dermal DCs (DDCs), which are both capable of activating naïve $\mathrm{T}$ cells $[39,40]$. During the development of chronic cutaneous inflammatory and autoimmune disorders, such as in psoriasis, Th17 and Th1 cells infiltrate the skin where resident DCs were shown to have a role in the initiation and maintenance of Th17 immunity $[41,42]$. Different observations suggested a possible association of the inflammatory lipid mediator PAF with psoriasis [29-32]. PAF is found in increased concentrations in inflammatory lesions and is a known regulator of transcription of a variety of cytokines [26] including IL6. Moreover, PAF appears very early in inflammation and can stimulate and be produced by a variety of cells such as monocytes, dendritic cells, and keratinocytes. In this context, we investigated whether PAF could affect the development of Th17 cells in a model of LC-T cell coculture.

In the present study we provide evidence that PAF could effectively modulate the development of Th17 cells. First, we found that PAF induced a rapid expression of IL-1 $\beta$, IL- 6 and IL-23 in human LC and keratinocytes, three cytokines reported to be crucial for Th17 development $[1,2]$. Second, we observed that TCR-activated T cells in coculture with PAF-stimulated LC, developed a Th17 phenotype with increased expression of the transcriptional regulator ROR $\gamma \mathrm{t}$ (and its human RORC2 mRNA equivalent) and associated molecules including IL-17A, IL-21 and IL22. Third, our findings demonstrate that blocking PAFR in LC-T cell cocultures impaired the expression of the transcriptional regulator $\mathrm{ROR} \gamma \mathrm{t}$ and that using anti-IL$6 \mathrm{R}$ and anti-IL-23 alone or in combination, abrogated the induction of ROR $\gamma$ t expression by PAF. Finally, we also found that PAF-induced Th17 development was dependent on cellcell contact between LC and T cells and that PAF enhanced the expression of Th17-associated markers via stimulation of LC rather than T-cells. Taken together, these observations suggest that generation of Th17 by LC is dependent on T cell interaction with LC and the production, by the latter, of cytokines such as IL-6 and IL-23 in response to PAF.
This kind of regulation of IL-17 production was also reported for another G-protein-coupled receptor. Sphingosine 1-phosphate (S1P), a biologically active lysophospholipid that binds to its receptor $\mathrm{S}_{1} \mathrm{P}_{1}$, was shown to have an effect similar to IL-23 in terms of increasing Th17 development from mouse splenic CD4 ${ }^{+} \mathrm{T}$ cells [43]. Moreover, in a recent review article, Edwards and Constantinescu suggested that the PAF/PAFR pathway may directly influence $\mathrm{T}$ cell responses and favour a Th17 phenotype, but no actual data were provided [28]. There are conflicting observations about whether human T lymphocytes express PAFR or not. Some authors reported that PAFR was not detectable on either resting [44] or activated T cells [45], but others observed low level expression on resting $\mathrm{T}$ cells which increased following stimulation $[28,44]$. However, in our model, TCR-activated highly purified human $\mathrm{CD}^{+} \mathrm{T}$ lymphocytes lacked PAFR expression and were unable to functionally respond to PAF stimulation. On the other hand, our results demonstrating that PAF can stimulate human LC and keratinocytes are in concordance with the literature which indicates that both DC and keratinocytes express functional PAFR [22, 46] and that PAF signalling activates LC migration [47]. As seen in our results, a bell-shaped concentration-response curve is regularly seen with GPCR ligands, where high concentrations do not elicit as good a response as mid-range concentrations. It is thought that autologous desensitization and internalization of the receptor, in response to high ligand concentrations, may be responsible for this phenomenon.

IL-17A and IL-17F both induce the production of various cytokines and chemokines, including TNF $\alpha$, IL- $1 \beta$, IL-6, IL-8, CCL2 (MCP-1), granulocyte colony-stimulating factor (G-CSF), as well as the expression of intercellular adhesion molecule (ICAM)-1 by monocytes, airway epithelial cells, vein endothelial cells, and fibroblasts. These IL-17-induced expression profiles can often be enhanced by TNF $\alpha$ and IFN$\gamma$ [48]. In the context of the skin, IL-17 has been reported to modulate the cytokine production and surface molecular make-up of epidermal keratinocytes. IL-17 enhanced the production of IL- 6 and IL- 8 in keratinocytes and induced a weak expression of ICAM-1 and HLA-DR [41], whereas IFN$\gamma$ and TNF $\alpha$-induced production of RANTES was markedly inhibited by IL-17 [49]. In addition, IL-17 has been reported to modulate fibroblast function by inducing their production of IL-6, IL-8, IL-11, GRO $\alpha$, and G-CSF [48].

In addition to IL-17A and IL-17F, Th17 cells produce other effector cytokines, namely, IL-21 and IL-22 [6]. Neither IL-21 nor IL-22 are Th17-exclusive cytokines, but are preferentially expressed in Th17 cells. IL-21 is produced mainly by $\mathrm{CD}^{+} \mathrm{T}$ cells [50] as well as by NKT cells [51]. Recently, several groups simultaneously observed that IL-21 was produced by Th17 cells upon stimulation by IL- 6 and by IL-21 itself and exerted critical functions in Th17 cell development [52-54]. The coexpression of IL-17 and IL-22 in Th17 cells suggests that the pathways that regulate these two cytokines might be very similar [55]. Although IL-23 is insufficient to induce de novo IL-17 production from naïve $\mathrm{CD}^{+} \mathrm{T}$ cells, IL-23 alone promotes IL-22 production from many different immune cell types. IL- 6 alone is sufficient for the induction of IL-22 from naïve $\mathrm{CD} 4^{+} \mathrm{T}$ cells. IL-22, 
therefore, might be an obvious downstream factor of IL23 that mediates the crosstalk between infiltrating immune cells, especially $\mathrm{T}$ cells, and keratinocytes in psoriatic skin. Injection of IL-23 into a mouse ear causes an inflammatory skin phenotype, characterized by leukocyte infiltration [54]. The infiltrating $\mathrm{CD} 4^{+} \mathrm{T}$ cells display a Th17 cell phenotype with the expression of both IL-17 and IL-22. In addition to IL-21 and IL-22, other cytokines such as TNF $\alpha$ and IL-1 $\beta$, which are not specifically produced by Th17 cells, have been proposed to have an additional role in the amplification of Th17 responses [56, 57]. PAF, a known activator of IL- $1 \beta$ and TNF $\alpha$ [58] could also participate in such an amplification loop. Recently, TLR2-activated human LC also were shown to promote the polarization of Th cells into Th17 cells via the production of IL- $1 \beta$, TGF $\beta$, and IL-23 [59].

Thus, PAF/PAF-R interactions may be involved in the early events leading to Th17 differentiation and trigger a selfamplification process. PAF may contribute to the creation of a proinflammatory environment that would skew cytokine production in favour of Th17 development. During the preparation of the present paper, Singh et al. [60] reported that in vivo blockade of PAF inhibited the development of psoriasis-like disease in a transgenic mouse model and the concomitant Th17 phenotype.

\section{Conclusion}

In the present work, we showed that PAF stimulates LC and keratinocytes to produce IL-6 and IL-23. Moreover, activated $\mathrm{T}$ cells in coculture with PAF-stimulated LC develop a Th17 phenotype with increased expression of the transcriptional regulator ROR $\gamma \mathrm{t}$ and enhanced production of IL-17, IL21 and IL-22. These effects are blocked by a PAF receptor antagonist and neutralizing antibodies to IL-6 and IL-23. These observations suggest that PAF can contribute to the differentiation of activated $\mathrm{T}$ cells into Th17 by inducing LC to produce IL- 6 and IL-23. This may constitute a previously unknown stimulus for the development and persistence of inflammatory processes that could be amenable to pharmacologic intervention.

\section{Abbreviations}

LC: Langerhans cell

PAF: Platelet-activating factor

PAFR: PAF receptor

ROR $\gamma$ t: Retinoic orphan receptor-gamma T

RORC2: Retinoic orphan receptor C2.

\section{Acknowledgments}

The authors wish to thank the blood donors for their selfless contribution to this work. AMD was supported by a studentship from the Fonds de la recherche en santé du Québec (FRSQ) and a studentship from Merck-Frosst. JS and MR-P were supported by a grant (MOP-6822) from the Canadian Institutes of Health Research. J. Stankovà and M. Role-Pleszczynski are members of the FRSQ-funded Centre de Recherche Clinique Étienne-Lebel. M. Rola-Pleszczynski was supported by a Canada Research Chair in Inflammation.

\section{References}

[1] E. V. Acosta-Rodriguez, G. Napolitani, A. Lanzavecchia, and F. Sallusto, "Interleukins $1 \beta$ and 6 but not transforming growth factor- $\beta$ are essential for the differentiation of interleukin 17producing human T helper cells," Nature Immunology, vol. 8, no. 9, pp. 942-949, 2007.

[2] N. J. Wilson, K. Boniface, J. R. Chan et al., "Development, cytokine profile and function of human interleukin 17producing helper T cells," Nature Immunology, vol. 8, no. 9, pp. 950-957, 2007.

[3] S. Aggarwal, N. Ghilardi, M. H. Xie, F. J. De Sauvage, and A. L. Gurney, "Interleukin-23 promotes a distinct CD4 $\mathrm{T}$ cell activation state characterized by the production of interleukin-17," Journal of Biological Chemistry, vol. 278, no. 3, pp. 1910-1914, 2003.

[4] C. L. Langrish, Y. Chen, W. M. Blumenschein et al., "IL-23 drives a pathogenic $\mathrm{T}$ cell population that induces autoimmune inflammation," Journal of Experimental Medicine, vol. 201, no. 2, pp. 233-240, 2005.

[5] N. Manel, D. Unutmaz, and D. R. Littman, "The differentiation of human $\mathrm{TH}-17$ cells requires transforming growth factor- $\beta$ and induction of the nuclear receptor ROR $\gamma \mathrm{t}$," Nature Immunology, vol. 9, no. 6, pp. 641-649, 2008.

[6] W. Ouyang, J. K. Kolls, and Y. Zheng, "The Biological Functions of T Helper 17 Cell Effector Cytokines in Inflammation," Immunity, vol. 28, no. 4, pp. 454-467, 2008.

[7] I. I. Ivanov, B. S. McKenzie, L. Zhou et al., "The orphan nuclear receptor ROR $\gamma$ t directs the differentiation program of proinflammatory IL-17+ T helper cells," Cell, vol. 126, no. 6, pp. 1121-1133, 2006.

[8] S. Burgler, N. Ouaked, C. Bassin et al., "Differentiation and functional analysis of human TH17 cells," Journal of Allergy and Clinical Immunology, vol. 123, no. 3, pp. 588-595, 2009.

[9] C. Lock, G. Hermans, R. Pedotti et al., "Gene-microarray analysis of multiple sclerosis lesions yields new targets validated in autoimmune encephalomyelitis," Nature Medicine, vol. 8, no. 5, pp. 500-508, 2002.

[10] K. Sato, A. Suematsu, K. Okamoto et al., "Th17 functions as an osteoclastogenic helper T cell subset that links T cell activation and bone destruction," Journal of Experimental Medicine, vol. 203, no. 12, pp. 2673-2682, 2006.

[11] C. K. Wong, C. Y. Ho, E. K. Li, and C. W. K. Lam, "Elevation of proinflammatory cytokine (IL-18, IL-17, IL-12) and Th2 cytokine (IL-4) concentrations in patients with systemic lupus erythematosus," Lupus, vol. 9, no. 8, pp. 589-593, 2000.

[12] D. Yen, J. Cheung, H. Scheerens et al., "IL-23 is essential for $\mathrm{T}$ cell-mediated colitis and promotes inflammation via IL-17 and IL-6," Journal of Clinical Investigation, vol. 116, no. 5, pp. 1310-1316, 2006.

[13] K. Kikly, L. Liu, S. Na, and J. D. Sedgwick, "The IL-23/Th17 axis: therapeutic targets for autoimmune inflammation," Current Opinion in Immunology, vol. 18, no. 6, pp. 670-675, 2006.

[14] J. Chakir, J. Shannon, S. Molet et al., "Airway remodelingassociated mediators in moderate to severe asthma: effect of steroids on TGF- $\beta$, IL-11, IL-17, and type I and type III collagen expression," Journal of Allergy and Clinical Immunology, vol. 111, no. 6, pp. 1293-1298, 2003. 
[15] C. K. Wong, C. Y. Ho, F. W. S. Ko et al., "Proinflammatory cytokines (IL-17, IL-6, IL-18 and IL-12) and Th cytokines (IFN- $\gamma$, IL-4, IL-10 and IL-13) in patients with allergic asthma," Clinical and Experimental Immunology, vol. 125, no. 2, pp. 177-183, 2001.

[16] M. A. Lowes, T. Kikuchi, J. Fuentes-Duculan et al., "Psoriasis vulgaris lesions contain discrete populations of Th1 and Th17 T cells," Journal of Investigative Dermatology, vol. 128, no. 5, pp. 1207-1211, 2008.

[17] C. Johansen, P. A. Usher, R. B. Kjellerup, D. Lundsgaard, L. Iversen, and K. Kragballe, "Characterization of the interleukin-17 isoforms and receptors in lesional psoriatic skin," British Journal of Dermatology, vol. 160, no. 2, pp. 319324, 2009.

[18] E. Lee, W. L. Trepicchio, J. L. Oestreicher et al., "Increased expression of interleukin 23 p19 and p40 in Lesional skin of patients with Psoriasis Vulgaris," Journal of Experimental Medicine, vol. 199, no. 1, pp. 125-130, 2004.

[19] G. Piskin, R. M. R. Sylva-Steenland, J. D. Bos, and M. B. M. Teunissen, "In vitro and in situ expression of IL-23 by keratinocytes in healthy skin and psoriasis lesions: enhanced expression in psoriatic skin," Journal of Immunology, vol. 176, no. 3, pp. 1908-1915, 2006.

[20] L. C. Zaba, I. Cardinale, P. Gilleaudeau et al., "Amelioration of epidermal hyperplasia by TNF inhibition is associated with reduced Th17 responses," Journal of Experimental Medicine, vol. 204, no. 13, pp. 3183-3194, 2007.

[21] E. Muller, P. Dagenais, N. Alami, and M. Rola-Pleszczynski, "Identification and functional characterization of plateletactivating factor receptors in human leukocyte populations using polyclonal anti- peptide antibody," Proceedings of the National Academy of Sciences of the United States of America, vol. 90, no. 12, pp. 5818-5822, 1993.

[22] J. B. Travers, J. C. Huff, M. Rola-Pleszczynski, E. W. Gelfand, J. G. Morelli, and R. C. Murphy, "Identification of functional platelet-activating factor receptors on human keratinocytes," Journal of Investigative Dermatology, vol. 105, no. 6, pp. 816823, 1995.

[23] Z. I. Honda, S. Ishii, and T. Shimizu, "Platelet-activating factor receptor," Journal of Biochemistry, vol. 131, no. 6, pp. 773-779, 2002.

[24] S. M. Prescott, G. A. Zimmerman, D. M. Stafforini, and T. M. McIntyre, "Platelet-activating factor and related lipid mediators," Annual Review of Biochemistry, vol. 69, pp. 419445, 2000.

[25] M. Thivierge and M. Rola-Pleszczynski, "Platelet-activating factor enhances interleukin-6 production by alveolar macrophages," Journal of Allergy and Clinical Immunology, vol. 90, no. 5, pp. 796-802, 1992.

[26] M. Rola-Pleszczynski, M. Thivierge, N. Gagnon, C. Lacasse, and J. Stankova, "Differential regulation of cytokine and cytokine receptor genes by PAF, LTB4 and PGE2," Journal of Lipid Mediators, vol. 6, no. 1-3, pp. 175-181, 1992.

[27] S. Ishii and T. Shimizu, "Platelet-activating factor (PAF) receptor and genetically engineered PAF receptor mutant mice," Progress in Lipid Research, vol. 39, no. 1, pp. 41-82, 2000.

[28] L. J. Edwards and C. S. Constantinescu, "Platelet activating factor/platelet activating factor receptor pathway as a potential therapeutic target in autoimmune diseases," Inflammation and Allergy_Drug Targets, vol. 8, no. 3, pp. 182-190, 2009.

[29] S. Izaki, T. Yamamoto, Y. Goto et al., "Platelet-activating factor and arachidonic acid metabolites in psoriatic inflammation," British Journal of Dermatology, vol. 134, no. 6, pp. 1060-1064, 1996.
[30] M. R. Judge, R. M. Barr, A. I. Mallet, F. Courtney, A. Kobza Black, and M. W. Greaves, "Platelet activating factor (PAF) and lyso-PAF in psoriasis," Archives of Dermatological Research, vol. 286, no. 7, pp. 376-379, 1994.

[31] C. Bayerl, H. Brandt, M. Niemczyk, K. Müller-Decker, and N. Gretz, "PAF-Receptor in inflammatory versus non inflammatory human epidermis, cell cultures and embryonal cells," Inflammation Research, vol. 52, no. 7, pp. 283-286, 2003.

[32] S. Sato, K. Kume, C. Ito, S. Ishii, and T. Shimizu, "Accelerated proliferation of epidermal keratinocytes by the transgenic expression of the platelet-activating factor receptor," Archives of Dermatological Research, vol. 291, no. 11, pp. 614-621, 1999.

[33] J. T. Elder, "IL-15 and psoriasis: another genetic link to Th17?" Journal of Investigative Dermatology, vol. 127, no. 11, pp. 24952497, 2007.

[34] M. Ziolkowska, A. Koc, G. Luszczykiewicz et al., "High levels of IL-17 in rheumatoid arthritis patients: IL-15 triggers in vitro IL-17 production via cyclosporin A-sensitive mechanism," Journal of Immunology, vol. 164, no. 5, pp. 2832-2838, 2000.

[35] V. Lukashova, Z. Chen, R. J. Duhé, M. Rola-Pleszczynski, and J. Staňková, "Janus kinase 2 activation by the plateletactivating factor receptor (PAFR): roles of Tyk2 and PAFR C terminus," Journal of Immunology, vol. 171, no. 7, pp. 37943800, 2003.

[36] Z. Pan, V. V. Kravchenko, and R. D. Ye, "Platelet-activating factor stimulates transcription of the heparin- binding epidermal growth factor-like growth factor in monocytes. Correlation with an increased $\kappa \mathrm{B}$ binding activity," Journal of Biological Chemistry, vol. 270, no. 14, pp. 7787-7790, 1995.

[37] W. Zhou, B. O. Ibe, and J. U. Raj, "Platelet-activating factor induces ovine fetal pulmonary venous smooth muscle cell proliferation: role of epidermal growth factor receptor transactivation," American Journal of Physiology-Heart and Circulatory Physiology, vol. 292, no. 6, pp. H2773-H2781, 2007.

[38] M. L. Cho, J. W. Kang, Y. M. Moon et al., "STAT3 and NF- $\kappa$ B signal pathway is required for IL-23-mediated IL17 production in spontaneous arthritis animal model IL-1 receptor antagonist-deficient mice," Journal of Immunology, vol. 176, no. 9, pp. 5652-5661, 2006.

[39] A. T. Larregina, A. E. Morelli, L. A. Spencer et al., "Dermalresident CD14+ cells differentiate into Langerhans cells," Nature Immunology, vol. 2, no. 12, pp. 1151-1158, 2001.

[40] A. E. Morelli, J. Peter Rubin, G. Erdos et al., "CD4+ T cell responses elicited by different subsets of human skin migratory dendritic cells," Journal of Immunology, vol. 175, no. 12, pp. 7905-7915, 2005.

[41] M. B. M. Teunissen, C. W. Koomen, R. De Waal Malefyt, E. A. Wierenga, and J. D. Bos, "Interleukin-17 and interferon$\gamma$ synergize in the enhancement of proinflammatory cytokine production by human keratinocytes," Journal of Investigative Dermatology, vol. 111, no. 4, pp. 645-649, 1998.

[42] A. J. van Beelen, M. B. M. Teunissen, M. L. Kapsenberg, and E. C. De Jong, "Interleukin-17 in inflammatory skin disorders," Current Opinion in Allergy and Clinical Immunology, vol. 7, no. 5, pp. 374-381, 2007.

[43] J. J. Liao, M. C. Huang, and E. J. Goetzl, "Cutting edge: alternative signaling of Th17 cell development by sphingosine 1-phosphate," Journal of Immunology, vol. 178, no. 9, pp. 5425-5428, 2007.

[44] C. Calabresse, M. C. Nguer, O. Pellegrini, J. Benveniste, Y. Richard, and Y. Thomas, "Induction of high-affinity paf 
receptor expression during T cell activation," European Journal of Immunology, vol. 22, no. 6, pp. 1349-1355, 1992.

[45] H. U. Simon, P. W. Tsao, K. A. Siminovitch, G. B. Mills, and K. Blaser, "Functional platelet-activating factor receptors are expressed by monocytes and granulocytes but not by resting or activated $\mathrm{T}$ and $\mathrm{B}$ lymphocytes from normal individuals or patients with asthma," Journal of Immunology, vol. 153, no. 1, pp. 364-377, 1994.

[46] S. Sozzani, D. Longoni, R. Bonecchi et al., "Human monocytederived and CD34+ cell-derived dendritic cells express functional receptors for platelet activating factor," FEBS Letters, vol. 418, no. 1-2, pp. 98-100, 1997.

[47] A. Fukunaga, N. M. Khaskhely, C. S. Sreevidya, S. N. Byrne, and S. E. Ullrich, "Dermal dendritic cells, and not Langerhans cells, play an essential role in inducing an immune response," Journal of Immunology, vol. 180, no. 5, pp. 3057-3064, 2008.

[48] J. K. Kolls and A. Lindén, "Interleukin-17 family members and inflammation," Immunity, vol. 21, no. 4, pp. 467-476, 2004.

[49] C. Albanesi, A. Cavani, and G. Girolomoni, "IL-17 is produced by nickel-specific $\mathrm{T}$ lymphocytes and regulates ICAM-1 expression and chemokine production in human keratinocytes: synergistic or antagonist effects with IFN- $\gamma$ and TNF- $\alpha$, Journal of Immunology, vol. 162, no. 1, pp. 494-502, 1999.

[50] J. Parrish-Novak, S. R. Dillon, A. Nelson et al., "Interleukin 21 and its receptor are involved in NK cell expansion and regulation of lymphocyte function," Nature, vol. 408, no. 6808, pp. 57-63, 2000.

[51] J. M. Coquet, K. Kyparissoudis, D. G. Pellicci et al., "IL-21 is produced by NKT cells and modulates NKT cell activation and cytokine production," Journal of Immunology, vol. 178, no. 5, pp. 2827-2834, 2007.

[52] T. Korn, E. Bettelli, W. Gao et al., "IL-21 initiates an alternative pathway to induce proinflammatory T H17 cells," Nature, vol. 448, no. 7152, pp. 484-487, 2007.

[53] R. Nurieva, X. O. Yang, G. Martinez et al., "Essential autocrine regulation by IL-21 in the generation of inflammatory T cells," Nature, vol. 448, no. 7152, pp. 480-483, 2007.

[54] L. Zhou, I. I. Ivanov, R. Spolski et al., "IL-6 programs TH-17 cell differentiation by promoting sequential engagement of the IL-21 and IL-23 pathways," Nature Immunology, vol. 8, no. 9, pp. 967-974, 2007.

[55] Y. Zheng, D. M. Danilenko, P. Valdez et al., "Interleukin-22, a TH17 cytokine, mediates IL-23-induced dermal inflammation and acanthosis," Nature, vol. 445, no. 7128, pp. 648-651, 2007.

[56] C. Sutton, C. Brereton, B. Keogh, K. H. G. Mills, and E. C. Lavelle, "A crucial role for interleukin (IL)-1 in the induction of IL-17-producing $\mathrm{T}$ cells that mediate autoimmune encephalomyelitis," Journal of Experimental Medicine, vol. 203, no. 7, pp. 1685-1691, 2006.

[57] M. Veldhoen, R. J. Hocking, C. J. Atkins, R. M. Locksley, and B. Stockinger, "TGF $\beta$ in the context of an inflammatory cytokine milieu supports de novo differentiation of IL-17-producing T cells," Immunity, vol. 24, no. 2, pp. 179-189, 2006.

[58] M. Rola-Pleszczynski, M. Thivierge, N. Gagnon, C. Lacasse, and J. Stankova, "Differential regulation of cytokine and cytokine receptor genes by PAF, LTB4 and PGE2," Journal of Lipid Mediators, vol. 6, no. 1-3, pp. 175-181, 1992.

[59] E. Aliahmadi, R. Gramlich, A. Grützkau et al., "TLR2activated human langerhans cells promote Th17 polarization via IL-1 $\beta$, TGF- $\beta$ and IL-23," European Journal of Immunology, vol. 39, no. 5, pp. 1221-1230, 2009.

[60] T. P. Singh, B. Huettner, H. Koefeler et al., "Platelet-activating factor blockade inhibits the T-helper type 17 cell pathway and suppresses psoriasis-like skin disease in K5.hTGF- $\beta 1$ transgenic mice," American Journal of Pathology, vol. 178, no. 2, pp. 699-708, 2011. 


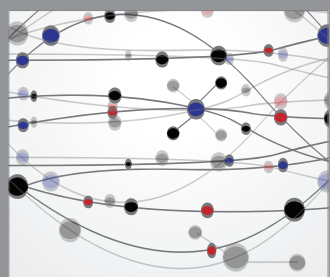

The Scientific World Journal
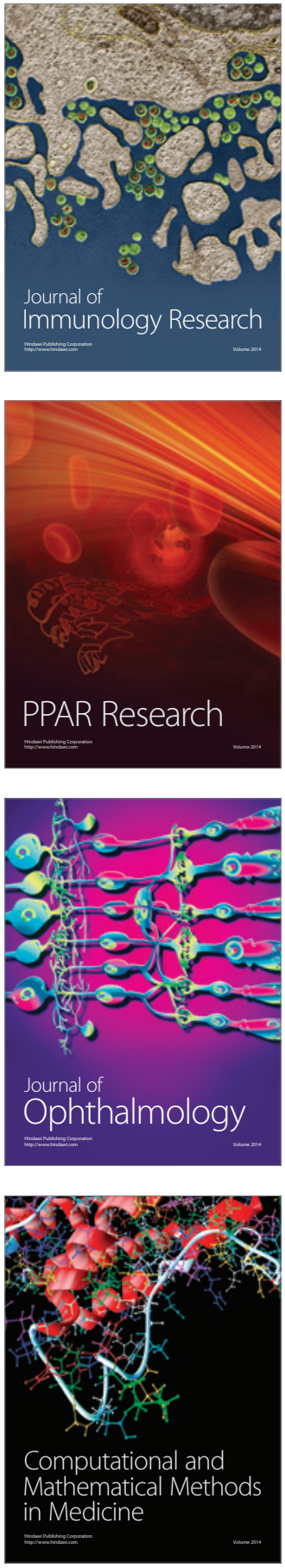

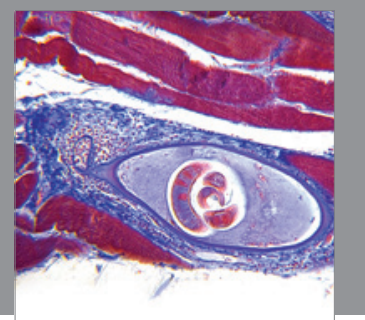

Gastroenterology

Research and Practice
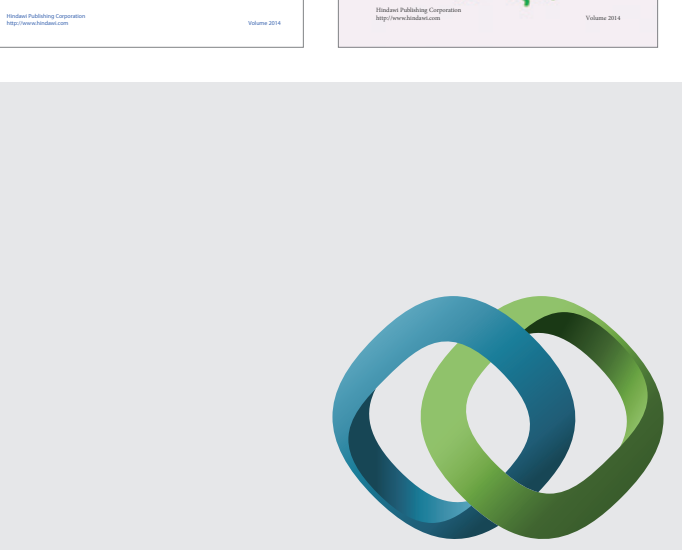

\section{Hindawi}

Submit your manuscripts at

http://www.hindawi.com
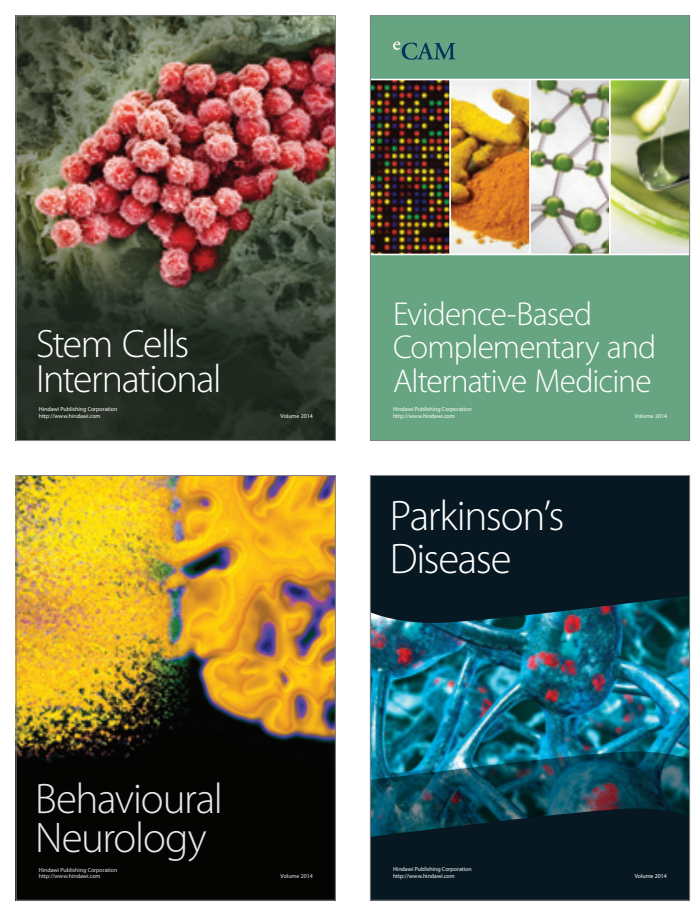

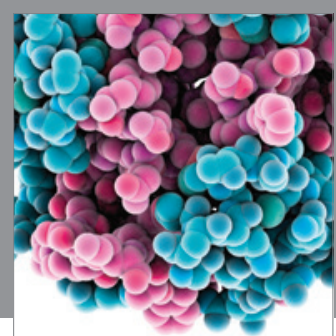

Journal of
Diabetes Research

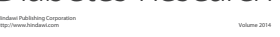

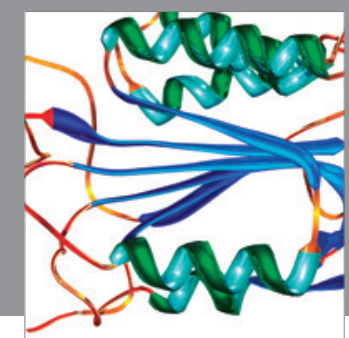

Disease Markers
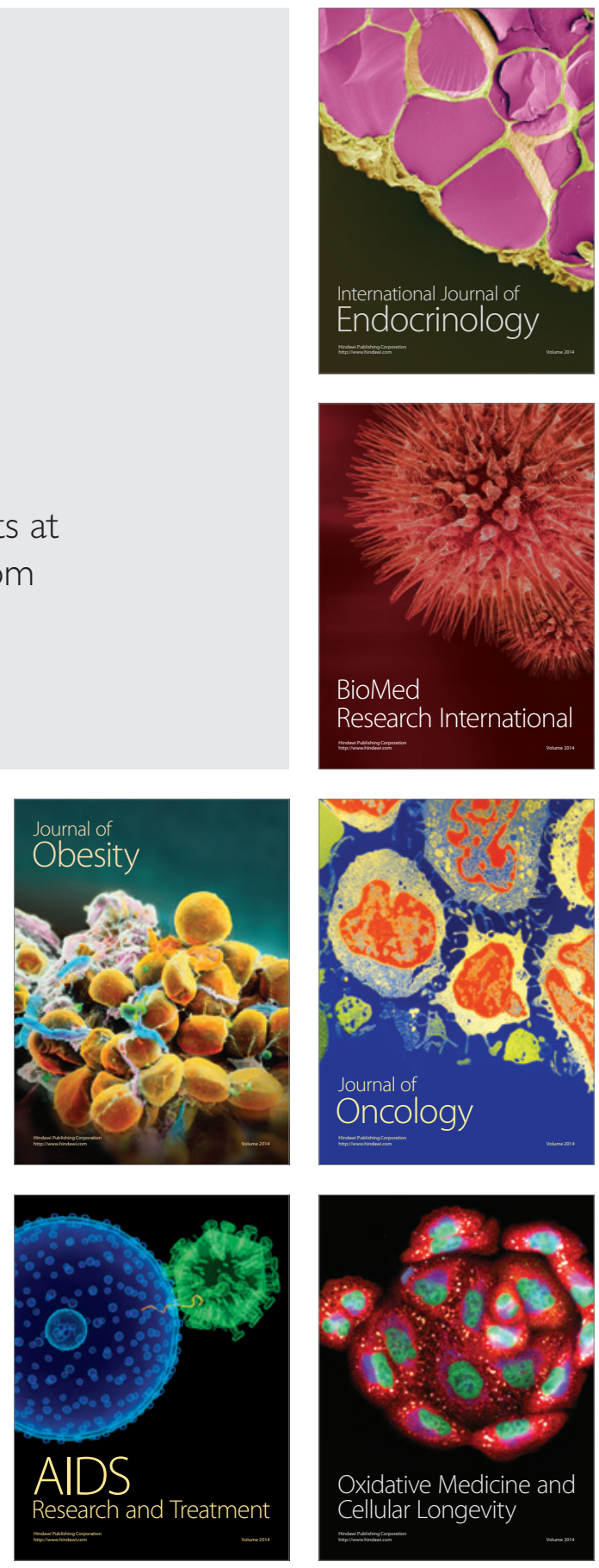